\title{
FIRST RECORD OF A SELF-SUSTAINING POPULATION OF ALPINE CHARR SALVELINUS UMBLA (LINNAEUS, 1758) (ACTINOPTERYGII, SALMONIDAE) IN SPAIN
}

\author{
Enric Aparicio* \\ *Institute of Aquatic Ecology, University of Girona, E-17071 Girona, Spain. enric.aparicio@gmail.com
}

\begin{abstract}
This work reports for the first time in Spain the presence of the non-native salmonid Alpine charr, usually included into Salvelinus alpinus, but recently revised to Salvelinus umbla. The species was found in a high mountain lake in the Pyrenees belonging to the Garonne catchment (Lake Obago, Val d'Aran, province of Lleida). This is probably not a recent introduction since the presence of one species of Salvelinus in some lakes of the Val d'Aran has been known among anglers for a long time, but the species identification was lacking. The distribution of S. umbla in the Val d'Aran appear to be restricted to a very few lakes and it has not spread downstream.
\end{abstract}

Key words: introduced species; Salmonidae; lakes; Pyrenees.

\section{RESUMEN}

Primera cita de una población naturalizada de salvelino alpino Salvelinus umbla (Linnaeus, 1758) (Actinopterygii, Salmonidae) en España

En este trabajo se cita por primera vez en España la presencia del salvelino alpino, generalmente incluido en Salvelinus alpinus, pero recientemente revisado como Salvelinus umbla. La especie fue encontrada en un lago de alta montaña de los Pirineos perteneciente a la cuenca del Garona (Estany Obago, Val d'Aran, Lleida). Probablemente no se trata de una introducción reciente ya que la presencia de una especie de Salvelinus en algunos lagos del Valle de Arán ya era conocida entre los pescadores durante mucho tiempo, pero la identificación de la especie no se había realizado. La distribución de S. umbla en el Valle de Arán parece estar restringida a unos pocos lagos y no se ha extendido a los tramos de río aguas abajo.

Palabras clave: especies introducidas; Salmonidae; lagos; Pirineos.

Recibido/Received: 16/08/2015; Aceptado/Accepted: 20/10/2015; Publicado en línea/Published online: 24/11/2015

Cómo citar este artículo/Citation: Aparicio, E. 2015. First record of a self-sustaining population of Alpine charr Salvelinus umbla (Linnaeus, 1758) (Actinopterygii, Salmonidae) in Spain. Grael/sia, 71(2): e034. http://dx.doi.org/10.3989/graellsia. 2015.v71.147

Copyright: (c) 2015 SAM y CSIC. Salvo indicación contraria, todos los contenidos de la edición electrónica de Grael/sia se distribuyen bajo licencia de uso y distribución Creative Commons Reconocimiento no Comercial 3.0. España (cc-by-nc).

\section{Introduction}

Arctic charr Salvelinus alpinus (Linnaeus, 1758) is a stenotherm salmonid restricted to cold water habitats, living from arctic to temperate climate regions of the Holarctic (Klemetsen et al., 2003). The systematics of S. alpinus in Europe is under review because this species exhibits a complex mosaic of variability in morphology and ecology throughout its range (Kottelat \&
Freyhof, 2007). Populations of Arctic charr present in Alpine and subalpine lakes in Italy, France, Switzerland, Germany and Austria were usually included into $S$. alpinus (Maitland, 1995), but recently were revised to Alpine charr Salvelinus umbla (Linnaeus, 1758) (Kottelat \& Freyhof, 2007). Salvelinus umbla has been widely introduced in numerous high altitude lakes of Europe because of its value as a sport fish. For example, $S$. umbla is native to only two lakes in France, but it is 
currently introduced in more than 130 lakes, about 38\% of them in the French Pyrenees (Machino, 1995).

In Spain, the information available on the possible presence of introduced populations of Salvelinus spp. is rather vague. Holčík (1991) reported that there were attempts to introduce S. alpinus in Spain (unknown waters), but the species was not established. Machino (1999) reviewed charr introductions in southern Europe and left open the possibility that S. umbla (referred in the original article as $S$. alpinus) was present in Pyrenean lakes of the Huesca and Lleida provinces. However, to date there are no confirmed records of the presence of S. umbla in natural waters of Spain (Machino, 1999 and references therein; Doadrio, 2002; Doadrio et al., 2011; Miró \& Ventura, 2013). The only Salvelinus species known to be present in Spain is the brook trout Salvelinus fontinalis (Mitchill, 1814), which was stocked in several lakes by government agencies in the 1970s and, as a consequence, self-sustaining populations currently exist in some lakes (Sostoa \& Lobón-Cerviá, 1989; Doadrio et al., 2011; Miró \& Ventura, 2013).

Val d'Aran is a Pyrenean valley situated at the headwaters of the Garonne catchment (Atlantic basin). Many glacial lakes exist in this area, which are regularly stocked with brown trout Salmo trutta Linnaeus, 1758 , for angling purposes. Besides $S$. trutta, in a few of these lakes the occurrence of one species of Salvelinus has been known among anglers for a long time, but up to now, the identification of the species was lacking. The goal of this work was to collect some specimens of Salvelinus sp. inhabiting in one of these lakes to identify the species they belong to.

\section{Materials and methods}

The study lake was Lake Obago (Lat. $42^{\circ} 36^{\prime} 50^{\prime \prime} \mathrm{N}$, Long. $\left.0^{\circ} 56^{\prime} 33^{\prime \prime} \mathrm{E}\right)$, situated in the Val d'Aran, Lleida province (Catalonia region) (Fig. 1). The lake is $640 \mathrm{~m}$ long and $345 \mathrm{~m}$ wide, with a total surface area of 13.4 ha. At 2,236 $\mathrm{m}$ above sea level, the maximum depth of the lake is $27.1 \mathrm{~m}$. Lake Obago is dimictic and covered with ice for 6-7 months a year.

Fish were collected by angling at Lake Obago in July 2015. Collected specimens of Salvelinus sp., after being photographed, were killed with a lethal dose of anaesthetic (MS-222) and frozen to be examined in the laboratory. One of the specimens has been deposited at the Fish Collection of the Museo Nacional de Ciencias Naturales (MNCN_ICTIO 290.843) (Madrid, Spain).

\section{Results}

A total of 12 fish were captured. Three fish were identified as Salvelinus umbla (Fig. 2) and the rest were S. trutta. Another fish species observed to be present in the lake was the European minnow Phoxinus sp. (Linnaeus, 1758).

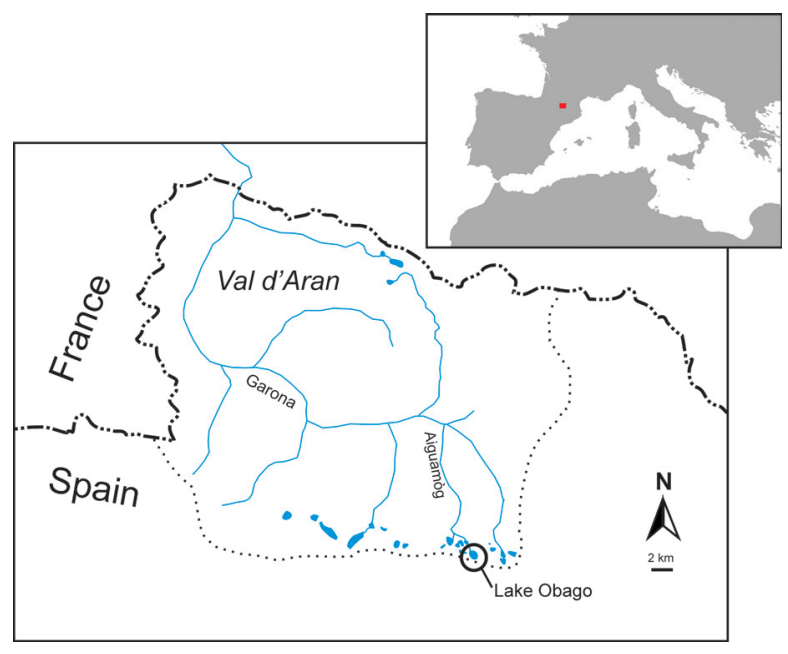

Fig. 1.- Geographical situation of Lake Obago in the Val d'Aran, province of Lleida.

Fig. 1.- Situación geográfica del Lago Obago en el Valle de Arán, provincia de Lleida.

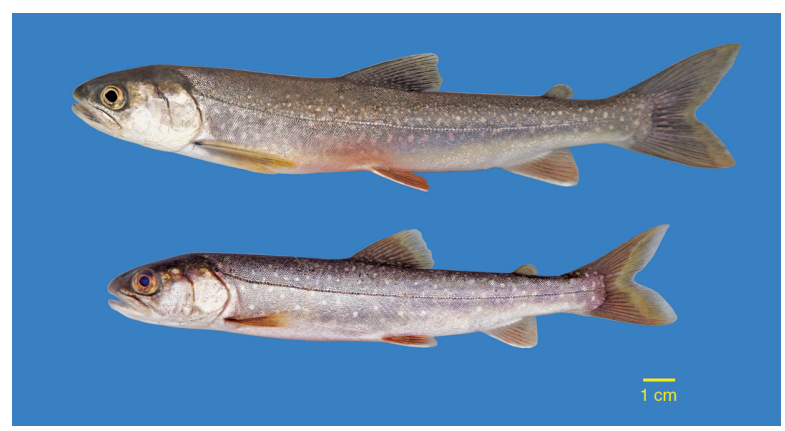

Fig. 2.- Specimens of Salvelinus umbla captured in Lake Obago in July 2015. Photographs by E. Aparicio.

Fig. 2.- Ejemplares de Salvelinus umbla capturados en el Lago Obago en Julio de 2015. Fotografías de E. Aparicio.

The three specimens of $S$. umbla measured 165 , 197 and $234 \mathrm{~mm}$ fork length. They were identified by the following characters: elongated body covered by small scales; soft spots on the body sides (whitish or pale pink colour) on a darker background; absence of a marbled pattern (vermiculated) on the back (typical of $S$. fontinalis); forward edge of pectoral, pelvic and anal fins with a white margin; caudal fin deeply forked; colouration bluish-gray on body flanks, whitish or rosy in the ventral part. Other characters useful to diagnose $S$. umbla are a terminal to subterminal mouth, lower jaw not included in upper jaw, and the presence of 25-31 gill rakers (Kottelat \& Freyhof, 2007).

\section{Discussion}

The current study confirms for the first time the presence of $S$. umbla in natural waters of Spain. They are present at least in Lake Obago, but according to personal communications from local fishermen, 
S. umbla may be present in two other lakes of Val d'Aran: Mar (Lat. $42^{\circ} 37^{\prime} 40^{\prime \prime} \mathrm{N}$, Long. $0^{\circ} 50^{\prime} 34^{\prime \prime} \mathrm{E}$ ) and Restanca (Lat. $42^{\circ} 38^{\prime} 3^{\prime \prime} \mathrm{N}$, Long. $0^{\circ} 51^{\prime} 11^{\prime \prime} \mathrm{E}$ ). The presence of $S$. umbla in Lake Obago is probably not a recent introduction because local fishermen regularly reported catches of Salvelinus sp. in this lake at least since the 1980s. This would also indicate that the population is self-sustaining (i.e. maintained by natural reproduction). The late confirmation of the presence of S. umbla in Spain could be attributed to its restricted range and the remote areas it inhabits.

The origin of the population of $S$. umbla in Lake Obago is unknown. Miró \& Ventura (2003) reported written records from Capdella hatchery (Province of Lleida) which indicated an introduction of $S$. fontinalis in Lake Obago in 1973. The possibility that the stocking records were wrong and the species stocked was $S$. umbla is unlikely, since other lakes stocked with $S$. fontinalis from the same hatchery and similar dates currently hold populations of this latter species (Miró \& Ventura, 2003). The most probable explanation of the origin of S. umbla in Lake Obago, according to interviews with local fishermen, is an introduction performed by the Catalonia Angling Federation (representative of angling clubs) at the beginning of the 1980s, with specimens presumably obtained from some french hatchery.

Salvelinus umbla in Lake Obago lives in sympatry with S. trutta and Phoxinus sp. All three species are introduced in this lake since most lakes in the Pyrenees are originally empty of fish due to natural barriers that prevented natural colonization of fish from downstream (Miró \& Ventura, 2013). Therefore, threats to other fish due to predation or competitive interactions caused by S. umbla in Lake Obago are not relevant from a conservation point of view, but the streams draining Lake Obago (Aiguamòg and Garona) support native populations of $S$. trutta and the endangered Cottus hispaniolensis Bacescu-Mester, 1964. Therefore, the possibility that $S$. umbla may invade downstream riverine habitats is a risk. However, this risk seems to be negligible since this species rarely thrives in running waters (Klemetsen et al., 2003), as is demonstrated by the fact that it is still confined to the lakes where it was introduced 30 years ago. On the other hand, $S$. umbla and other introduced fish could threaten the biodiversity of native amphibians and invertebrates in high mountain lakes through predation (e.g. Brancelj, 2000; Knapp et al., 2001). The magnitude of possible impacts should be assessed and remedial action taken if needed.

\section{Acknowledgements}

The author is grateful to Dr. Gerard Carmona-Catot for his helpful comments and the English revision of the manuscript.

\section{References}

Brancelj, A., 2000. The extinction of Arcotodiaptomus alpinus (Copepoda) following the introduction of charr into a small alpine lake Dvojno Jezero (NW Slovenia). Aquatic Ecology, 33: 355-361. http://dx.doi.org/10. 1023/A:1009972108485

Doadrio, I., 2002. Atlas y Libro Rojo de los Peces Continentales de España. Dirección General de Conservación de la Naturaleza. Madrid. 364 pp.

Doadrio, I., Perea, S., Garzón-Heydt, P. \& González, J. L., 2011. Ictiofauna Continental Española. Bases para su seguimiento. Dirección General Medio Natural y Política Forestal, Ministerio de Medio Ambiente y Medio Rural y Marino. Madrid. 616 pp.

Holčík, J., 1991. Fish introductions in Europe with particular reference to its central and eastern part. Canadian Journal of Fisheries and Aquatic Sciences, 48: 13-23. http://dx.doi.org/10.1139/f91-300

Klemetsen, A., Amundsen, P. A., Dempson, J. B., Jonsson, B., Jonsson, N., O’Connell, M. F. \& Mortensen, E., 2003. Atlantic salmon Salmo salar L., brown trout Salmo trutta L. and Arctic charr Salvelinus alpinus (L.): a review of aspects of their life histories. Ecology of Freshwater Fish, 12: 1-59. http://dx.doi.org/10.1034/ j.1600-0633.2003.00010.x

Knapp, R. A., Matthews, K. R. \& Sarnelle, O., 2001. Resistance and resilience of alpine lake fauna to fish introductions. Ecological Monographs, 71: 401-421. http:// dx.doi.org/10.1890/0012-9615(2001)071\%5B0401:RA ROAL\%5D2.0.CO;2

Kottelat, M. \& Freyhof, J., 2007. Handbook of European freshwater fishes. Publications Kottelat. Cornol. 646 pp.

Machino, Y., 1995. The status of Salvelinus in France. Nordic Journal of Freshwater Research, 71: 352-358.

Machino, Y., 1999. History and status of Arctic charr introductions in southern Europe. ISACF Information Series, 7: 33-39.

Maitland, P. S., 1995. World status and conservation of the arctic charr Salvelinus alpinus (L.). Nordic Journal of Freshwater Research, 71: 113-127.

Miró, A. \& Ventura, M., 2003. Història de la truita comuna $i$ altres espècies de peixos als estanys del parc nacional d'aigüestortes i estany de sant maurici: orígens, aprofitament i distribució. VI Jornades sobre recerca al Parc Nacional d'Aigüestortes i Estany de Sant Maurici, Espot (Lleida): 1-25.

Miró, A. \& Ventura, M., 2013. Historical use, fishing management and lake characteristics explain the presence of non-native trout in Pyrenean lakes: Implications for conservation. Biological Conservation, 167: 17-24. http:// dx.doi.org/10.1016/j.biocon.2013.07.016

Sostoa, A. de \& Lobón-Cerviá, J., 1989. Fish and fisheries of the River Ebro: actual state and recent history. In: G. E. Petts, H. Möller \& A. L. Roux (eds.). Historical Changes of Large Aluvials Rivers: Western Europe. John Wiley \& Sons. Chichester: 233-247. 